\section{Analysis Of The Actual Consumption Of Milk And Dairy Products By The Population Of The Ferghana Valley Of The Republic of Uzbekistan}

\begin{abstract}
Normatova Shakhnoza Anvarovna, Phd, Associate Professor, Deputy Director For Research And Innovation, Ferghana Branch Of The Tashkent Medical Academy Ferghana, Uzbekistan
\end{abstract}

\author{
Ruzmatova Khiloloy Kabilovna, \\ Assistant Of The Department Of Hygiene And Public \\ Health, \\ Ferghana Branch Of The Tashkent Medical Academy, \\ Uzbekistan
}

Gopen access

The American Journal of Medical Sciences And Pharmaceutical

Research

JULY 2020

Page No.: 43-47

Volume-II Issue-VII

PUBLISHED: 30 JULY 2020

www.usajournalshub.com/inde

x.php/TAJMSPR

Copyright: Original content from this work may be used under the terms of the

Creative Commons Attribution

4.0 licence.

\title{
Abstract
}

The article is devoted to the study of the actual consumption of milk and dairy products used by the population of the Fergana Valley. The object of the study was the food rations of the population and milk consumed by the population, produced by dairy enterprises and private farms in Fergana, Namangan and Andijan regions. The study was carried out using an active questionnaire method. The results of the study showed that the actual consumption of milk and dairy products by the population of the Fergana Valley is 2.5 times lower than the hygienic standards; it was revealed that in the structure of dairy products, kefir is $34 \%$, milk $23 \%$, sour cream $9 \%$, ayran and suzma $7 \%$, other dairy products are below $4 \%$.

Keywords: actual nutrition, milk, dairy products, analysis, population.

\section{Introduction}

According to the WHO, the world demand for milk per capita is $500 \mathrm{~g}$, dairy products 900-1000 g per day. But the actual consumption of milk and dairy products in many developed countries is decreasing day by day. In the USA, the consumption of milk and dairy products is $37 \%$, in Germany

- $15 \%$, in Great Britain - $20 \%$, in Russia - 36\%, in our country - $42 \%$ below the norm. Lack of milk and dairy products in the diet contributes to the emergence of many diseases, including those related to nutrition, which is a medical and social problem [4]. 
To increase the effectiveness of measures for the prevention and treatment of diseases associated with malnutrition, as well as to study the role and significance of food in the world, a wide range of scientific research is being carried out; Of particular importance is the scientific substantiation of the composition of the diets of various groups of the population, associated with the level of physical and neuropsychic stress, the state of health of the studied groups, proving the importance of dairy products in the prevention of diseases, developing measures to provide the population with high-quality and safe food, developing measures to improve the quality of milk and dairy products during their production [5].

During the years of independence in our country, the healthcare sector has been radically renewed, broad-based program activities are being carried out, including scientific research on the prevention, early detection, diagnosis and treatment of diseases associated with malnutrition, such as diseases of the gastrointestinal tract, anemia, osteoporosis, metabolic disorder in the body. According to the Action Strategy for five priority areas of development of the Republic of Uzbekistan in 2017-2021, further improvement of the provision of medical care to the population of the country is planned. One of the priority tasks awaiting its decision is the timely prevention and diagnosis of diseases associated with malnutrition and malnutrition. Providing the population with healthy food will improve the quality of life of various groups of the population [11].

The problems of food quality and safety are studied by scientists from different countries of the world $[6,10]$. In this direction, WHO has developed a global strategy to provide the population with safe food, reduce morbidity and develop social conditions [15]. Foreign scientists have carried out a number of studies on the ethological aspects and forecasting of dairy products of cows, the development of an integrated technology for dairy products of a given level of quality and functional focus, the study of the quality of dairy raw materials and the commodity assessment of dairy products, the formation of a branding strategy for milk and dairy products, the microbiology of dairy products, management market relations in the production of dairy products $[7,8,9,12]$.

In Uzbekistan, the problems of actual nutrition have been studied, the deficiency in the diet of proteins, fats, carbohydrates, vitamins and microelements has been determined, the epidemiology of various diseases (anemia, hepatitis, ischemic heart disease, etc.) related to nutrition has been studied and the principles of rational nutrition have been developed for various population groups [ 1, 2, 3, 13, 14]. However, in the problem of the hygienic value of milk and dairy products, a number of unresolved issues remain, such as determining the actual consumption of milk depending on the season of the year, gender and age, family income. The hygienic conditions of milk and dairy products production, the peculiarities of the technological process leading to the contamination of milk and dairy products have not been studied, the total contamination of milk and dairy products with foreign substances has not been studied enough, methodological recommendations have not been developed for monitoring the quality and safety of milk and dairy products.

Literary data showed that today in our republic the role of milk and dairy products in the nutrition of the population has not been broadly covered and measures have not been developed to ensure the safety of dairy products during production. This requires a deep study of the problem of ensuring the quality and safety of dairy products in Uzbekistan. 
Purpose of the study: hygienic assessment of the actual consumption of milk and dairy products in hot climates.

\section{Materials And Research Methods}

The object of the study was the food rations of the population and milk consumed by the population, produced by dairy enterprises and private farms in Fergana, Namangan and Andijan regions. Subject of research: studying the role of dairy products in the nutrition of the population and assessing the safety of dairy products during their production. To solve the set tasks, hygienic, chemical, instrumental and statistical research methods were used. A hygienic assessment of the actual consumption of milk and dairy products was carried out among the population of the city of Fergana, Fergana, Namangan and Andijan regions. The study of the actual nutrition was carried out by the method of questionnaires (2131 questionnaires). The calculation of the actual consumption of milk and dairy products was carried out taking into account gender, age, seasons (winter-spring, summer-autumn). In these regions, the nutritional status was studied, a hygienic assessment of the actual nutrition was given, which was compared with the recommended norms (San R and N 0105-01).

Statistical processing of quantitative data was carried out using the EXCEL software package on a Pentium-4 computer. The average statistical value of the indicators (M), standard deviation $(\delta)$, series error $(m)$, Student's test $(t)$ were determined, with the calculation of the error probability $(P)$ and others. Differences were considered significant at $\mathrm{P}<0.05$.

\section{Results And Discussion}

The results showed that $75 \%$ of the population consumes milk once, $5 \%-2$ times a day, $20 \%$ of the population does not consume milk at all. The survey data showed that $95 \%$ of the population regularly consumes dairy products (kefir, kaymak, sour cream, cottage cheese). Of the total number of respondents, $90 \%$ selectively consume dairy products once a day, and only $10 \%$ - 2 times a day. $50 \%$ of the urban population buys dairy products from their hands or at the bazaar, $40 \%$ of the surveyed people buy them in shops or supermarkets. The study of the seasonality of milk consumption showed the statistical insignificance of the differences.

According to FAO / WHO data, milk consumption in developed countries is $67.5 \mathrm{~kg}$ per year, i.e. $187.5 \mathrm{~g}$ per day. The results of the analysis of questionnaires to assess the actual consumption of milk showed an insufficient level of consumed amount of this product (Table 1) The average amount of milk consumed in the study region is set at $144.4 \mathrm{~g}$.

\section{Table 1}

Actual daily consumption of milk and dairy products by the population of the Fergana Valley $(M \pm \mathbf{m})$ 
THE AMERICAN JOURNAL OF MEDICAL SCIENCES AND PHARMACEUTICAL RESEARCH

ISSN (e): 2689-1026

DOI: https://doi.org/10.37547/TAJMSPR/Volume02Issue07-07

\begin{tabular}{|l|l|l|l|l|l|l|}
\hline Product name & $\begin{array}{l}\text { Men } \\
\mathbf{1 0 7 9}\end{array}$ & $\begin{array}{l}\text { Women } \\
\mathbf{1 0 5 2}\end{array}$ & $\mathbf{t}$ & $\mathbf{P}$ & $\begin{array}{l}\text { Total } \\
\mathbf{2 1 3 1}\end{array}$ & \% \\
\hline Milk & $141,1 \pm 14,6$ & $147,8 \pm 15,2$ & 0,32 & $>0,05$ & 144,4 & 23 \\
\hline Cream & $25,47 \pm 3,3$ & $32,07 \pm 2,3$ & 1,64 & $>0,05$ & 28,77 & 4 \\
\hline Kefir & $226,2 \pm 6,2$ & $194,0 \pm 4,5$ & 4,20 & $<0,001$ & 210,1 & 34 \\
\hline Ayran & $57,75 \pm 6,2$ & $31,27 \pm 7,8$ & 2,66 & $<0,01$ & 44,51 & 7 \\
\hline Sour cream & $59,54 \pm 7,0$ & $53,78 \pm 6,1$ & 0,62 & $>0,05$ & 56,66 & 9 \\
\hline Cheese & $15,98 \pm 2,3$ & $15,46 \pm 1,8$ & 0,18 & $>0,05$ & 15,72 & 3 \\
\hline Brynza & $13,92 \pm 0,9$ & $10,84 \pm 1,8$ & 1,53 & $>0,05$ & 12,8 & 2 \\
\hline Suzma & $43,69 \pm 5,6$ & $45,33 \pm 5,4$ & 0,21 & $>0,05$ & 44,51 & 7 \\
\hline Curdled milk & $22,43 \pm 4,5$ & $23,59 \pm 6,8$ & 0,14 & $>0,05$ & 23,01 & 4 \\
\hline Ryazhenka & $21,49 \pm 2,1$ & $25,90 \pm 1,2$ & 1,82 & $>0,05$ & 23,33 & 4 \\
\hline Yogurt & $16,81 \pm 0,9$ & $21,31 \pm 1,2$ & 3,00 & $<0,01$ & 19,21 & 3 \\
\hline TOTAL: & $\mathbf{6 4 4 , 4}$ & $\mathbf{6 0 1 , 4}$ & & & $\mathbf{6 2 2 , 9}$ & $\mathbf{1 0 0}$ \\
\hline
\end{tabular}

The given data indicate that the amount of milk consumed by the population of the Fergana Valley is lower than national and international norms. With a low consumption of milk by the population, a large amount of grain products, bread, black and green tea was noted in the diet.

According to Table 1, among men and women there is a statistical difference in the consumption of kefir $(P<0.001)$, ayran $(P<0.01)$ and yogurt $(P<0.001)$ : among the male population, kefir and ayran are consumed more, and among women - yogurt. In the daily diet of dairy products, kefir is $33.7 \%$, milk is in second place $-23.2 \%$, sour cream $9.1 \%$, ayran and suzma $7.1 \%$, the rest of dairy products are less than $4 \%$. If a person consumes on average about $2.5 \mathrm{~kg}$ of food during the day, then $24.88 \%$ of it is dairy products. It is calculated that $28.1 \mathrm{~g}$ of protein, $46.78 \mathrm{~g}$ of fat, $22.16 \mathrm{~g}$ of carbohydrates and $5.08 \mathrm{~g}$ of organic acids enter the body as part of the daily consumption of milk and dairy products. The total energy value of these products is $682.1 \mathrm{kcal}$ or $3139 \mathrm{~kJ}$. According to scientifically based norms, milk and dairy products should make up one third of the diet (1000 calories of the average daily human requirement of 3000 calories).

\section{Conclusions}

1. The actual consumption of milk and dairy products by the population of the Fergana Valley is 2.5 times lower than the hygienic standards; it was revealed that in the structure of dairy products, kefir is $34 \%$, milk $23 \%$, sour cream $9 \%$, ayran and suzma $7 \%$, other dairy products are below $4 \%$.

2. Implementation of organizational, sanitary-hygienic, sanitary-technical, preventive measures for the production, transportation, storage and sale of dairy products (guidelines No. 012-3 / 1047) guarantees the production of high-quality and safe dairy products. 


\section{References}

1. Azizova F.L. Hygienic substantiation of the effectiveness of the use of new food products in the complex treatment of viral hepatitis // Abstract of the thesis for the degree of candidate med. sciences. Tashkent, 2004. 12 p.

2. Alimukhamedov D. Sh. Hygienic substantiation of prevention and treatment of iron deficiency anemia in children and adolescents living in rural areas of Uzbekistan // Diss. ... Cand. honey. sciences. - Tashkent, 2006. - 112 p.

3. Baykulov A. A. Medical and biological substantiation of hygienic criteria for food, biological value and safety of cotton oil obtained under various technological modes // Dissertation. ... Cand. honey. sciences. - Tashkent, 2003. - 126 p.

4. Normatova Sh. A., Bakhritdinov Sh. S. Actual consumption of milk and dairy products and assessment of the degree of their contamination // Hygiene and Sanitation. - Moscow, 2011. - №2. - P. 65-67.

5. Normatova Sh. A. Analysis of the actual use of dairy products per capita in the daily diet of various groups of the population // Toshkent tibbiyot academyasi ahborotnomasi. Toshkent, 2014. -№1. - P. 64-67.

6. Normatova Sh. A. Hygienic assessment of dairy products in the daily diet of the population, taking into account gender and age // Uzbekiston tibbiet journals. -Toshkent, 2014. -No3. - P. 68-71.

7. Ponomarev A. N. Methods of control of procured milk // Dairy industry. 2005. - No. 2. P. 21.

8. Smirnov A.A. Hygienic foundations of quality and safety of dairy products in modern production conditions // Author. dis. ... Cand. honey. sciences. - St. Petersburg. - 2008. $18 \mathrm{p}$.

9. Stepanenko P. P. Microbiology of milk and dairy products / M .: Lira, 2015. - $196 \mathrm{p}$.

10. Tutelyan V. A., Sukhanov B. P., Onishchenko G. G. State policy of healthy nutrition of the population: tasks and ways of implementation. / A guide for doctors. - Moscow, Geotar-Media. - 2009. - 288 p.

11. Decree of the President of the Republic of Uzbekistan. Action strategy for five priority areas of development of the Republic of Uzbekistan in 2017 - 2021 // Tashkent, February 7, 2017. No. 4947.

12. Fedyaev P. M. State regulation of the milk and dairy products market: on the materials of the Kemerovo region // Dissertation. ... Cand. econ. sciences. - Novosibirsk, 2016. - 176 p.

13. Khudoiberganov A.S. Tasks of health authorities to improve nutrition of the population in Uzbekistan // Actual problems of hygiene, ecology and public health. - Fergana, 2007. P. 108-109.

14. Shaikhova GI, Abdurakhimova K. Sh., Azizova FL, Tolibboev NS Hygienic assessment of the sanitary and anti-epidemic regime of children's preschool institutions // Actual problems of the environment and public health. - Fergana, 2009. - P. 33-34.

15. WHO Commission on Macreconomics and Health.Macroeconomicsand belth: investinq in bealth for economic development. - Qeneva. WHO. 2001. 